\title{
„Nem szólhatván, az Úristent segítségül hívta” - A fonák okság kifejezéséről középmagyar szövegekben*
}

1. Bevezetés. A dolgozatban megengedést kifejező mondatszerkezetek variációját vizsgálom 16-18. századi szövegekben, elsődlegesen a Történeti magánéleti korpuszt (TMK.; NovÁK et al. 2017) felhasználva. A sajátos jelentéstartalmú mondatszerkezetek közül a megengedőt tartja a legkésőbb kialakultnak a szakirodalom - ez vélhetően összefügg a jelentésbeli összetettségével is (BERRÁR 1957; RÁCZ 1995; HAADER 2000 - ezek részletes tárgyalását 1. lentebb). Ráadásul kifejezőeszközeit tekintve: „még mindig fejlődőben levő nyelvi kategória”; „mindig újabb és újabb formák jönnek létre” (BERRÁR 1956: 34). ${ }^{1}$ A variáció a középmagyarban a megengedő mellékmondatok különféle kötőszós változatai és az eddig kevesebbet tárgyalt határozói igeneves szerkezetek váltakozó, egymásnak megfeleltethető mondatszerkezetekben való használatát jelenti: ${ }^{2}$

(1) ,jól lehet nála Esztendeig lakot azon Aszony de reája semmit ollyast nem latott nem is tud" (Bosz. 2. 115. sz., 1746)

(2) „Egy hazban lakván ezen fatens Portörő Ersokkal, de soha roszszat hozzá nem látott” (Bosz. 2. 12. sz., 1702)

A szociolingvisztikai felfogás szerint azok a szerkezetek is variánsnak tekinthetők, amelyek ugyan nem mutatnak szerkezeti rokonságot, a közös diskurzusbeli funkció viszont összekapcsolja öket (pl. will és going to, TAGLIAMONTE 2010: 74-75; szemben a formálisabb irányzatokkal, ahol a strukturális levezethetöség is kritérium). Ebben az esetben is a szerkezetek használatbeli megfelelése ad alapot a variációhoz, a megengedés egyaránt épülhet időre, okságra és ellentétre (ahogy a hagyományos, kötőszós variánsok is (1. 2.3.). Az igeneves és az alárendelő szerkesztésmód szinonímiáját ${ }^{3}$ az motiválja, hogy az igenév ugyanúgy bővülhet, mint az ige, a mellékmondatos megoldások azonban redundánsabbak, „szellősebbek” (HAADER 2000: 518, 2004: 466-467). Míg az alárendelő tagmondatok általában csak egy jelentést fejeznek ki világosan, explicit módon (a kötőszó és/vagy az utalószó által), addig a határozói igeneves szerkezetek egyszerre tudnak időt, okot,

* A tanulmány az MTA Nyelvtudományi Intézetben zajló 116217 számú OTKA-projektum anyagait felhasználva készült.

${ }^{1}$ Más nyelvekben is: „Moreover, in European languages at least, a wide variety of concessive markers is available and new items are constantly added to this class" (KÖNIG 1985: 1).

${ }^{2} \mathrm{Az}$ adatokat a kötetek alapján betűhűen közlöm, a hivatkozás a kötet Történeti magánéleti korpuszban alkalmazott rövidítése, a per/levél száma és az év alapján történik.

${ }^{3}$ A két változat referenciálisan ugyanazt az eseményt írja le, a megfogalmazás módjában azonban eltér - megkülönböztetve a formai variánsoktól, amelyek ,alaki eltérésük ellenére - nem mutatnak jelentéskülönbséget; tehát tetszőlegesen felcserélhető (illetve nyelvtörténeti jelenségek esetében: az adatok tanúsága alapján ilyennek feltételezhető) elemek" (DÖMÖTÖR 2003: 450-451).

Magyar Nyelv 113. 2017: 59-74. DOI: 10.18349/MagyarNyelv.2017.1.59 
eszközt, célt stb. kifejezni, ebben pedig inkább a mellérendelő mondatszerkesztésre hasonlítanak (GUGÁN 2002: 35-39; CREVELS 2000: 49-50).

A határozói igeneves szerkezetek a történeti mondattanok szerint a ,a megengedő mondatoknak megfelelö, azokat rövidítő határozók" (RÁCZ 1995: 711, 1. még BERRÁR 1977: 177, 181), valamint az igenévnek „régen is, ma is tulajdoníthatunk megengedő határozói szerepet” (BERRÁR 1977: 181). Ezzel szemben a középmagyar korszak magánéleti nyelvhasználatában (tanúvallomások és magánlevelek alapján) sokkal inkább a tagmondat értékủ használatuk mutatkozik meg (1. 4. pont). Ez az igenév szerkezeti tulajdonságainak megfelel: „A határozói igenév megőrizve igei vonzatait, különösképpen alanyát, mellékmondatszerü" (LENGYEL 1989: 190).

A sajátos jelentéstartalmú alárendelő tagmondatok esetében két fő változási irányra lehet következtetni. Az egyik az önálló, mellérendelő értékűvé válás, a másik pedig a mondatrésszé alakulás (HAADER 2008a, 2017). Az oksági viszonyokat kifejező mondattípusok között az ómagyarban átjárhatóság figyelhető meg: az okadó magyarázó és a megszorító utótagú ellentétes mondatokat nem tisztán mellérendelőnek nevezi a szakirodalom (vö. HAADER 1992: 97-98), míg a megengedő tagmondat eleve lazábban kapcsolódik a fömondatához, s gyakran elszakad a mondatrészkifejtéstől (RÁCZ 1995: 712-713; HAADER 2000: 518, 522523; más nyelvekben is, vö. KÖNIG 2006: 820). Felmerül tehát a kérdés, hogy a korszakban melyik változási tendencia érvényesül, és ezt hogyan befolyásolja az, hogy a korszak vége felé már kimutatható a mondatrészértékủ létére használata.

A dolgozat azokhoz a kutatásokhoz kíván csatlakozni, amelyekben a pragmatikai szemléletmód elötérbe kerül - ezt a kérdésfeltevés több tekintetben is indokolja. A pragmatikai megközelítés a mondattani és szövegszintü jelenségek esetében jobban érvényesíthető, hiszen a nyelvhasználónak ezeken a nyelvi szinteken többnyire variánsok egész sora áll rendelkezésére, így nagy szerepet kap a választhatóság (HAADER 2004: 465). A megengedő jelentéstartalmat pedig célszerü a mondattani mellett pragmatikai változónak is tekinteni, részben az alárendelő változat többféle eredete miatt (beleértve az ellentétes mellérendelés egyes fajtáihoz való viszonyát is), részben pedig azért, mert a határozói igeneves szerkezetek aktuális funkciója a szövegösszefüggés alapján azonosítható.

\section{2. „Átvezetés”: kiindulópontok, háttérfeltevések}

2.1. Elméleti kiindulás. A grammatikai változás fokozatosan, változatok versengésében realizálódik: a rendszer belső változatossága és rendezett sokféleség jellemzi a nyelv szerveződését (WEINREICH-LABOV-HERZOG 1968: 183-184). Ez a szemlélet a hazai nyelvtörténetben régóta ismeretes: ,a szerkezeti vagy nyelvtani szinonimák végeredményben funkcionális variánsok [...] maga a nyelvtörténet is sok tekintetben nem más, mint e konkurrensek(!) harca" (KÁROLY 1980: 45). A megengedő jelentéstartalom története kapcsán is megfogalmazódott: ,a nyelvi elemek harcát, egymásutánjuk dinamikáját is vizsgálni kell” (BERRÁR 1956: 35).

A változó két vagy több alternatív módját foglalja magába az ugyanazt mondásnak (WEINREICH-LABOV-HERZOG 1968: 159, 178-179). Az „,ugyanaz” a morfológiai, szintaktikai és pragmatikai vizsgálatokban elsősorban funkcionális megfelelésként, hasonló diskurzusbeli müködésként értelmezhető (a definíció újraértelmezését 
részletesen 1. TAGLIAMONTE 2010: 73-78, 2012: 72-75, 111-114). A variációra jellemző a szerkezeti beágyazottság (úgynevezett variációs kontextus), valamint az, hogy megfeleltethető nyelvi és/vagy társadalmi mintázatokkal, csoportokkal.

2.2. A jelenségről. A sajátos jelentéstartalmak között a megengedés számít a legkomplexebbnek, történetileg a legfiatalabbnak (más nyelvekben is); összetettségére utal az a tény is, hogy a nyelvelsajátítás viszonylag késői szakaszában jelenik meg (KöNIG 1985: 1-2). Legjellemzőbben kötőszókkal fejezhető ki (noha nem példátlan az aszindeton, a kapcsolóelem nélküli szerkesztés sem, föként a szövegszintü használatban; CREVELS 2000: 96-104). Előfordul továbbá prepozíciókkal (az angolban ilyen a despite és az in spite of; KÖNIG 1985: 11; GROTE et al. 1997: 90-92), illetőleg alternatívái lehetnek különféle participiális mondatszerkezetek is (GIVÓN 1990: 835; CREVELS 2000: 42-45).

A megengedés egyik (hagyományos történeti) elnevezése, a fonák okság a jelenség jellegzetes jelentés-összetevőjére utal, hasonló terminusok használatosak más nyelvekben is (anticause, incausal, inoperant cause, hidden causality; KöNIG 2006: 820). A fonák okság azt jelenti, hogy a mellékmondat tartalmából következik valami, azonban a főmondat másról tudósít: „nem az ok-okozat teljesül, hanem az ok-fonák okozat" (HAADER 2000: 522). A mellékmondatban implikált beszélöi előfeltevés az egyik lehetséges, de épp nem aktuális alternatíva (BÁNRÉTI 1983: 10-11). Megengedéssel olyan szituáció is leírható, amely egy általános tendenciát (előfeltevést) tekintve kivételes, ezért figyelemreméltó (KÖNIG 2006: 821).

2.3. Szemantikai előzmények. A jelentéstartalom azon az előfeltevésen, implicit vélekedésen alapul, hogy a mellékmondat és a fömondat tartalma között összeegyeztethetetlenség, konfliktus érzékelhető (a két szituáció, helyzet normális, standard körülmények között nem jár együtt) - az elöfeltevés pedig aktuálisan törlődik (KÖNIG 1985: 4). Emellett jelezheti a váratlan, meglepő jellegét az épp elhangzottaknak (a korábbiak fényében; GROTE et al. 1997: 89-91). Jellemzően a határozói tagmondat hordozza az alapokat, a főmondat pedig a váratlan vagy kevéssé valószínủ eseményt, helyzetet fejezi ki (GIVÓN 1990: 835).

A magyarban a megengedést kifejező kötőszókészlet igen változatos, összefüggésben azzal is, hogy e jelentéstartalomnak többféle elözménye is lehetett. Az egyik forrás a megszorító ellentétes tagmondat, melyben számos ráhagyást jelző elem alakult ki: igaz, bizony, valóbizony, alighogy, jóllehet, akár, bátor (BERRÁR 1957: 172-173; RÁCZ 1995: 712-714). Maga az ellentétes mondat kötőszava is megengedővé válhatott, mint a pedig vagy a maga (vagy demaga), ezek mellé társulhattak hasonló funkciójú elemek, mint a jóllehet. Az ok-okozati összefüggés pedig megváltozhat (azaz fonák okság érvényesül), ezt jelölheti a (de) azért 'annak ellenére' (RÁCZ 1995: 717-718).

A feltételt és időt kifejező tagmondatokban szintén megjelenhetett a megengedő jelentéstartalom (föként nem várt következmény esetén). Az ilyen tagmondatokban ezt a jelentést jellemzően ellentétes mellérendelő kötőszók nyomatékosítják; ilyen a ha-(is); ha-(de); ha-(mégis); noha, hol holott (az angolban hasonlóan müködik az if 'ha' és a hozzá kapcsolódó ún. fókuszpartikulák; KÖNIG 1985: 11). A tipológiai munkák szerint a térbeli és időbeli viszonyokat kifejező elemek speciális kontextusban logikai grammatikai viszonyok jelölőivé 
grammatikalizálódhatnak. A megengedő kapcsolóelemek egyik forrása az időhatározói kötőszó, annak két fajtája is; a folyamatot, tartósságot kifejező (pl. az angol while 'mialatt' > 'noha'), és az olyanok is, amelyek egyaránt jelenthetnek folyamatot és mozzanatot (HEINE-KUTEVA 2002: 293).

2.4. Mit enged meg a megengedés? Ahogy az első két példában láttuk, az ellentétes kötőszók (mint az angol but, nálunk pedig többek között a de) szintén kifejezhetnek megengedést (manapság is, pl. John szegény. De boldog). A váratlanság, az összeférhetetlenség az előfeltevéseinktől függ, minden megengedés implikál szembeállítást is (GROTE et al. 1997: 90-92). Az angol beszélt nyelvben a megengedés nem feltétlenül ritka, viszont jellemzőbb mellérendelő de-konstrukciókkal, mint jóllehet-konstrukciókkal (BARTH 2000: 412, 417). Ilyenkor nem feltétlenül a tagmondatbeli tények, tartalmak összeegyeztethetetlenek, hanem a belölük együttesen levonható konklúzió az, amit összeférhetetlennek tekint a beszélő, ellentétes kapcsolóelemek és a may vagy hasonló jelentésủ modális elemek fejezik ki (pl. He may be a professor, but he is an idiot; KÖNIG 2006: 823). Szemantikailag közel áll továbbá a megengedéshez a substitutive-nak nevezett jelentés, mivel pragmatikai előfeltevést, összeférhetetlenséget ez is jelez, de kizárólagos formában, míg a megengedés csupán az együttállás szokatlanságát hangsúlyozza (de mindkét tagmondatbeli esemény/állapot egyszerre igaz lehet, vö. GIVÓN 1990: 836). ${ }^{4}$ Ha szemantikailag elkülönül is a megengedés, formailag sem a modern angolban, sem a modern németben nem éles köztük a különbség; ez alapján az ellentét általánosabb és alapvetőbb viszony, a megengedés ennek specifikusabb változata (KÖNIG 1985: 7).

A magyarban szintén nem problémamentes a megengedés egyes fajtáinak és az ellentétnek az elválasztása: az utóbbi az előbbinek az egyik történeti előzménye, ma pedig mellérendelő párhuzama (elsősorban a megszorító utótagú; HAADER 2000: 522). — A sajátos jelentéstartalmak viszont határozói viszonyokat kifejtő mellékmondatokra épülnek rá, időre, (időből) feltételességre, okságra (vö. az angol és a német kapcsán 1. KÖNIG 1985, más nyelvekben CREVELS 2000), így az alárendelés körébe tartoznak. A formális leírás szerint a független alárendelésbe tartozó tagmondatoknak „olyan strukturális elhelyezkedésben kell lenniük, melyben egyik fönévi csoport sem vezérli a másikat, de azért mégsem mellérendelés a tagmondatok viszonya" (KENESEI 1992: 545).

A formai-szerkezeti különbségek - a tagmondatok felcserélhetők, a kötőszó elöl is állhat, valamint a névmások megelőzhetik azt, amire referálnak - tehát a magyarban meghatározóbbnak tủnnek az elhatárolásban (noha korábban a besorolása vitatott volt, 1. BERRÁR 1956: 26; BÁNRÉTI 1983: 103). ${ }^{5}$ Az okságot kifejező mondatszerkezetek tartalmi alapú átjárhatósága miatt azonban nálunk is érvényes tehát az, hogy az ellentétes és a megengedő jelentésviszonyok közötti különbség elsődlegesen szemantikai és/vagy pragmatikai kritériumokon alapul (KÖNIG 1985: 6).

2.5. Lévén létére megengedő? Az igenév szerepe. A szinkrón rendszerben „a független alárendelésnek az a feltétele, hogy az alárendelő mondat kötőszava

\footnotetext{
${ }^{4}$ Substitutive: Instead of beeing tall, Joe is short ('Ahelyett, hogy magas lenne, Joe alacsony'); Concessive: Although Joe is tall, he is agile ('Noha Joe magas, mégis fürge'; GIVÓN 1990: 836).

${ }^{5}$ BÁNRÉTI ZOLTÁN (1983: 103) szerint a megengedő tagmondatok szemantikai tulajdonságai - a beszélöi előfeltevések kifejezése - miatt a mellérendeléshez áll közelebb, míg szintaktikai tulajdonságai, elsősorban a kötőszók alapján egyaránt mutat alá- és mellérendelő tulajdonságokat.
} 
sajátos jelentéstartalmánál fogva képes legyen jelölni az alárendelt mondatnak a főmondatban betöltött jelentéstani szerepét" (É. Kiss 1998: 130). A történeti megközelítés szerint viszont a rendszert a kapcsolóelemek változatossága mellett szerkezeti szempontból is gazdagabbnak tekinthetjük. Az ómagyarban a megengedő jelentéstartalmat elsődlegesen mellékmondat fejezte ki, ritkábban határozó (vö. mégis MünchK. valuad és valuatok; RÁCZ 1991: 546-549). Nem teljesen példátlan ugyanakkor a -ván/-vén képzős határozói igenévi szerkezet ilyen használata (RÁCZ 1992: 547; 1995: 712):

(3) „hoǵh merÿek en zolnom az vr ÿstennek por hamu lewen” (1521: Könyvecse 35$)$

(4) „yob tee neked eg̈ zemmel az erek eletre be menned honnem ket zemed lewen az erek tÿzre vettethny" (1516-1519, JordK. 410)

A lévén a későbbiekben is - a többi határozói igenévtől egyébként nem különbözve - kifejezhet többek között időt, okságot, fonák okságot is. Idővel azonban egyre inkább olyan kontextusokban fordul elö, ahol a szövegkörnyezetből oksági viszony következtethetö ki. Ez nem az igenévképző jelentésének a része; a szövegösszefüggés alapján továbbra is azonosítható az idő, az okság és a fonák okság is: „Későnkelők lévén, R. csak azért is reggelre rendelt magához” (MTSzt.; a lévén kötőszói használatának forrásszerkezetei kapcsán 1. GUGÁN 2015: 40-42).

Az igeneves szerkezetek tipikusan kötőszó nélkül kapcsolódnak a fómondatukhoz, ami azt is jelenti, hogy a köztük lévő logikai viszony értelmezése nem specifikus és bizonytalan is lehet. A két tagmondat egymáshoz való szemantikai viszonyának értelmezésében és az igenév funkciójának azonosításában a pragmatikai tényezők játsszák a fő szerepet (számos európai nyelvben, vö. KÖNIG - VAN DER AUWERA 1990: 337, 343).

A középmagyar kort tekintve az igenév története szempontjából is érdemes megvizsgálni a kérdést. Az igenév ekkor más nem-finit szerkezetektől eltérően saját alannyal is használatos, a fömondat és az igeneves tagmondat bővítményei között pedig koreferencia lehet (vö. GUGÁN 2006: 69-72). A TMK. morfológiailag elemzett adatbázisában keresve a -ván/-vén képzős igenév szembetünően gyakoribb, mint -va/-ve képzősek (jelenleg 837 találat, míg a -ván/-vén képzősek 7552 találatban fordulnak elö). Funkcióit tekintve pedig mind a levelekben, mind a perszövegekben számos használatára van példa - idő, ok, feltétel, állapot, mód, sőt finit szerepben is (VARGA 2015). A számos funkció azonban pragmatikai, mivel nem az igenévképző jelentésének a része. - A határozói igenév sajátos jelentéstartalma mindig komplex, épülhet időre, okságra (és ellentétre), így mindig lényeges az azonosításhoz a szövegösszefüggés, illetőleg a pragmatikai háttér:

(5) ,[az vizben vettessek,] ki bele vettetven fenekre nem ment, hanem czak fön lebegett” (Bosz. 2. 250. sz., 1665)

Az igeneves szerkezet ebben a szövegrészletben alapvetően időhatározónak tünik ('mikor belevettetett'), viszont ebben az esetben a boszorkányság bizonyításának egyik eljárásáról, a vízpróbáról (más néven fürösztésröl) van szó, amit több 
esetben maguk a vádlottak is kérhettek, hogy ártatlanságukat igazolják - mint ezúttal is: „hogy igaz az hogy eö mondotta volna azt, vessek az vizben eötet, es ha ala nem mégyen, bator megh egessek". A szövegelőzmény ismeretében már azonosítható a szokatlan együttállást implikáló megengedő jelentéstartalom 'noha belevettetett [a vízbe], fenékre nem ment', azaz mégsem tudta bizonyítani ártatlanságát.

Ahogy már láttuk, több esetben közvetlenül összevethetők a hasonló eseményeket különbözőképpen megformáló - mégis részben hasonló, párhuzamba állítható szerkezetủ mellékmondatos és igeneves - megoldások, akár egyazon szövegben is; ez szintén segíti a jelentéstartalom azonosítását:

(6a) „leányának férjez adásakor (noha Kereszt Annya volt) lakadalmában nem hivatatta Deák Györné [ti. a boszorkánysággal vádolt személyt]” (Bosz. 2. 404. sZ., 1756)

(6b) ,[kire gyanakodnék ...] felelé, hogy Morocz Jánosnéra, mivel köröszt komám lévén a midőn Leanyomat férhez attam, Lakodalomban nem hivatattam" (Bosz. 2. 404. sz., 1756)

Az adatok azt mutatják tehát, hogy a középmagyar korszakban a változatos kötőszókészlet mellett szerkezeti variáció is a beszélők rendelkezésére állt. A tagmondatsorrendet tekintve állhat a fömondat előtt és ritkábban utána is, valamint mellérendelő kötőszó (és, de) utáni tagmondatba ékelődve. Emellett a megengedő tagmondatok változatai is halmozódhatnak:

(7) „Kalos Palnenak szomszedsagaban lakvan a fatens, Szabo Miklosnevalis pedig egjütt lakot de semmit hozzajok nem tud sem hallot" (Bosz. 1. 58. sz., 1709)

Továbbá előfordul, hogy kötőszóval (és további ellentétes kapcsolóelemekkel) jelölt és igeneves tagmondatok állnak egymás közvetlen közelében, illetőleg egymásba ékelődve. Az alábbi példában igeneves szerkezettel kifejezett megengedésbe ('jóllehet a fatens azelött ugyan semmiképpen nem szólhatott, [most] az Úristent segítségül hívta') ékelődik bele egy további megengedő mellékmondat, s ez is nyomatékosítja az időbeli kontrasztot, s az ebből eredő összeférhetetlenséget:

(8) „,fatensis, az elött ugyan semmiképpen, noha tellyes erejével igyekezett, nem szolhatván az Ur Istent segécségül hitta” (Bosz. 2. 359. sz., 1741)

Ahogy a kifejezőeszközök között arról volt szó, más nyelvekben is kifejezheti a megengedést (határozói) igeneves szerkezet. CREVELS szerint például a spanyolban a gerundium ki tud alakítani megengedő olvasatot az alárendelö tagmondatban, $\mathrm{s}$ a nem-finit igeforma átveszi a funkcióját a hiányzó kapcsolóelemnek (ezeket nem tekinti aszindetonnak, az utóbbit a mellérendeléshez közelebbinek tartja; CREVELS 2000: 95). Az olaszban viszont kapcsolódhatnak emfatikus és fókuszpartikulák (pl. pur(e) 'mégis') az igeneves szerkezethez, megengedő jelentés esetén is (KÖNIG VAN DER AUVERA 1990: 343-344). Az angolban a megengedés beágyazottsága szempontjából kialakítható egy skála a különféle nem-finit szerkezetekből, en- 
nek finit végponthoz közeli változatában prepozíció teszi világossá a jelentést, de a nem-finit formának vannak igei kategóriái (az alanya alanyesetü, a tárgya tárgyesetü), megőrzi az igei alap belső szintaxisát a részleges deverbalizálódás ellenére (CREVELS 2000: 45). Annyi bizonyos, hogy a magyarban a határozói igenév önmagában nem ad megengedő olvasatot, ugyanakkor a középmagyarban a beágyazottság szempontjából a finit végponthoz áll közelebb, mivel több igei kategóriáját is megőrizte (1. 4. pont).

3. A feldolgozott nyelvi anyag. A jelen kutatásban a variációs lehetőségek megmutatása is a központi célok közé tartozik, részben a történeti jellegből adódóan, részben mert nem egy előre meghatározott mögöttes változás korlátainak, szabályainak müködése a kérdés. Így arra sem vállalkozom, hogy a változatok elöfordulásának valószínüségét szabályba foglaljam, noha ez elvárás a variacionista kutatásokban. A fonológiai vizsgálatokkal ellentétben a diskurzusformák és pragmatikai jelenségek esetében nem lehet szembeállítani az előfordulást és a hiányt, mivel az elöfordulás nyelvi környezete nem megjósolható, még ha lehetséges is olyan kontextusokat meghatározni, amelyek előnyben részesítik ezek használatát (DubOIS-SANKOFF 2001: 283; 1. még MACAULAY 2002: 284-285).

Szükséges viszont a lehetséges variánsok példányalapú feltárása (SCHNEIDER 2002: 88-89), fóként a ritkább, nehezebben azonosítható szerkezeti alternatíva esetén, mint az igeneves szerkezet. Ez azért is fontos, mert a szintaktikai és a pragmatikai megoldások esetén is be kell bizonyítani, hogy nem egyszeri, hanem rendszeres(ebb)en használt jelenségről van szó (HAADER 2004: 465). A megengedő jelentéstartalmú határozói igeneves szerkezetek feltárása a középmagyarban azért is lényeges, mert eddig nem mutatták ki, hogy ez a használat rendszeres-e. Az ómagyar kapcsán RÁCZ ENDRE idéz példákat a jelenségre, azonban igen ritkának tekinti (1995: 711-712). HORVÁTH LÁSZLÓ határozói igeneves vizsgálatában 1570-1615 és 16701715 között 3-3 ún. ,létére jelentésü igenév" fordul elő, mindegyik létigei eredetü, a legkésőbbi 1700-ból való (valószínüleg ezért vetődik fel, hogy ,a lévén és a létére mai használatában nem az eredeti funkciók cseréjét látjuk-e"; HORVÁTH 1991: 38).

Ezúttal a vizsgált anyag a folyamatosan bővülő Történeti magánéleti korpuszból származik. Az adatbázis teljes egészében morfológiailag elemezve van, így lehetőség volt nemcsak a kötőszókra, hanem a -ván/-vén képzős igenevekre is rákeresni (hiszen közel sem csak a lévén használatos ebben a funkcióban). Ez utóbbira jelenleg 7552 találatot hoz ki a korpusz (ebből 5444 boszorkányperekből származik), egy szövegrészletben több igeneves szerkezet is lehet. Mivel a határozói igenév számos diskurzusbeli funkciója használatos mind a levelekben, mind a tanúvallomásokban, az adatokat szürni kellett manuálisan. A szövegösszefüggés és - ahol lehetett - a kötőszós használattal való megfeleltetés segítségével így 276 megengedő jelentéstartalmú igeneves szerkezetet azonosítottam.

Az alábbi táblázat az igeneves megoldás megoszlását mutatja, összevetve a korpuszban leggyakoribb megengedő kötőszókéval. A forrásokat tekintve érdemes külön kezelni a boszorkánypereket és a leveleket. Mivel az utóbbiak egyikében (Károlyi Sándor írásaiban) a müfajhoz képest kiemelkedik az igeneves alternatíva, ezt külön is szemléltetem, a többi levél forrásai: a Telegdy-, Nádasdy-, vala- 
mint Zrínyi-levelezés, Lobkowitz Poppel Éva családi levelezése, Barkóczy Krisztina levelei Károlyi Sándorhoz, illetőleg peregrinuslevelek.

\section{1. táblázat}

Megengedő kötőszók és igeneves szerkezetek a TMK. alapján

\begin{tabular}{|c|c|c|c|c|}
\hline & igeneves & jóllehet & noha & holott \\
\hline Bosz. & 202 & 133 & 104 & 71 \\
\hline Kár. & 49 & 56 & 108 & 18 \\
\hline $\begin{array}{c}\text { Tel.; Nád.; Lobk.; Zr.; } \\
\text { Bark.; Peregr. }\end{array}$ & 25 & 126 & 151 & 21 \\
\hline Összesen & 276 & 315 & 363 & 110 \\
\hline
\end{tabular}

A kötőszók esetében általában nem kellett manuális szürést végezni, a holott kivételével, ez ugyanis lehet feltételes használatú (24 előfordulás), illetve megfelelhet az 'ahol' jelentésnek (35 esetben). ${ }^{6} \mathrm{~A}$ variánsok megoszlása nem egységes az egyes forrásokban: az igeneves szerkezet láthatóan jellemzőbb a tanúvallomásokban, míg egyes levelezésekben kifejezetten szórványos (a Telegdy- és Nádasdyírásokban 2-2 alkalommal fordul elö). A megengedő kötőszók szintén változatos megoszlásúak, a jóllehet kifejezetten jellemző a Nádasdy-levelekben (62 adat), míg a noha a peregrinuslevelek kedvelt megengedő jelentésü kapcsolóeleme (82 adat, arányaiban a holott is több, 19 előfordulás). Meg kell azonban jegyezni, hogy Lobkowitz Poppel Éva családi levelezését és a Zrínyi-leveleket tekintve kötőszós és igeneves használatban egyaránt kevéssé jellemző a megengedő jelentéstartalom.

$\mathrm{Az}$ igeneves szerkezet mint variáns időbeli terjedése ezekből az adatokból nem határozható meg, a korpusz alapján jelenleg csupán „helyzetjelentésre” van mód. Az adatbázis legkorábbi előfordulása 1560-ból való, a legkésőbbi pedig 1760ból. A 16. századi adatok száma igen csekély (4) - azonban a korpuszba (még) nem került források alapján ebböl nem lehet határozott következtetéseket levonni. A Kolozsvári boszorkányperek anyagában ugyanis szintén nem példátlan a jelenség:

(9) „Bizony szégyen, hogy öreg ember lévén oly kicsiddel fekszik” (Kolozsbosz. 151. sZ., 1584)

A 17. századi előfordulások száma jelenleg 25 (9 levélből, 16 tanúvallomásból), vagyis a 18. század adatai többszörösét adják ki a megelőző két évszázadnak. Az adatszám jelentős megemelkedése részben azzal magyarázható, hogy a korpuszban több forrás található ebből az időszakból; a tanúvallomásokra jellemző, hogy a 18. századból többször annyi forrás maradt fenn, mint korábbról, emellett

${ }^{6} \mathrm{~A}$ bátor bár és az akár lehet megengedő jelentésű, ugyanakkor a korpuszban nemcsak csekélyebb adatszámmal fordulnak elő (bátor bár: 130 33; akár 70), hanem inkább jellemzőjük a ráhagyó funkció (az akár esetében a választó is). A megengedő használat inkább kivételesnek számít: „Az vadat köszönöm, bár többet ne küldj” (Nád. 1554); ,,akar szaz Tyuknak Tojassa volna egy rakasson, a maga tyukok tojássat mind meg esmerne eő" (Bosz. 1. 33. sz. 1722). 
ebből az időszakból a levelezések is terjedelmesebbek. Az utóbbi szövegtípus inkább az egyéni nyelvhasználatról árulkodik, hiszen a korábbiakhoz képest a peregrinuslevelekben és Károlyi Sándor írásaiban összességében is jelentősen több -ván/-vén képzős igenév adatolható.

4. Megengedő jelentéstartalom a középmagyarban: kifejezőeszközök, változatok. Ahogy arról már volt szó, a kései ómagyarban a megengedő kötőszóknak számos változata használatos, átmeneti formákkal: jóllehet(hogy), no (+ ha), bárha habár stb. (RÁCZ 1995: 712-723). A középmagyarban szintén változékony, megállapodatlan az eszközkészlet; egyaránt jellemző a kapcsolóelemek alaki (bátor > bár) és funkcionális változása is (ugyan, megszorító ellentétes kötőszók támogatásával: de, mindazáltal stb.). A pedig (és változatai) ekkor már önmagában is kifejezi ezt a jelentést, emellett a holott is gyakoribbá válik. A kapcsolóelemek használatbeli alakulását jól mutatja, hogy az eszközök gyakran halmozódnak: kötőszók, ráhagyó-megengedő jelentésű partikulák, mondatszók, valamint megszorító utótagú ellentétes mellérendelő kötőszók (de, mégis) is nyomatékosítják a kifejezni kívánt jelentést (HAADER 2003: 684-685). A halmozott használatú kapcsolóelemekre a tanúvallomásokban és levelekben is találunk példákat, sőt a tendencia erősségét az is mutatja, hogy a határozói igeneves szerkezeti változatban is megfigyelhető:

(10) „hogy szemére vetette, noha ugyan átkozódással tagadta, de mindazonáltal nem sok üdő alatt e Fatens Felesége a magok házában edgyütt voltak, történt, hogy el sivakodott" (Bosz. 2. 441. sz., 1756)

(11) „én nem ok nélkül irtam, $s$ jól lehet most sem értem, mind az által már nem kérdem" (Kár. 269. sz., 1722)

(12) „Andrássi Uram bár tüllem várt volna, mégh sem gyülekezvén bé az Berinyi Urak $s$ nem conferálhattam rolla" (Kár. 249. sz., 1722)

(13) „az német Enyedet felégette. Jóllehet azután utánna menvén az kurucok, noha nem sokat, de mégis felest vágtak le bennek" (Bark. 50 sz., 1704)

A szerkezeti alternatívák pragmatikai hátterére rátérve a két jelenleg vizsgált szövegtípus közül egyértelmúen a tanúvallomás az, amelyben a megnyilatkozók előnyben részesítik a megengedő jelentésű szerkezeteket, beleértve az igeneves variánst is (noha statisztikailag a többi alárendeléshez viszonyítva nem kiemelkedő, ahogy a többi műfajban sem a korszakban; vö. HAADER 2008b: 253-255).

A megengedő jelentés több pragmatikai-kommunikációs célra is használatos, ezek leginkább a szembeállítás, a kontraszt jelzésével történnek (a befogadó meggyőzése érdekében), valamint a világról való általános tudás szempontjából szokatlan, váratlan együttállás kifejezésekor a hibás/nem adekvát implikatúrák kivédése, megelőzése, valamint az informálás meglepő eseményekről, hasonlóképpen az általános elvárások felfüggesztését kihasználva (GROTE et al. 1997). A tanúvallomásokban nem ritkán hangsúlyosan szokatlan, váratlan együttállások szerepelnek, általában a boszorkánysággal kapcsolatba hozva. Jellegzetesen ilyen a boszorkány szokatlan viselkedése vagy éppen a hirtelen megbetegedések; ez utóbbi időbeli szembeállításon is alapulhat: 
(14) ,az üdő alatt oly nagy hideget bocsatott reá (noha előb ép és egésséges volt) hogy az maga házáigh alligh mehetett" (Bosz. 2. 433. sz., 1751)

(15) ,az alatt megh nehezedvén nagy hirtelenségel az elött nagy egésséges friss iffju lévén más fél heti csudalatos beteghségében megh holt" (Bosz. 2. 411. sz., 1732)

Ettől nem válik el élesen az éppen nem érvényes (implicit) vélekedés, következtetés kivédése, megelőzése. Ezek jellemzően okviszonyon alapuló megengedések, 'azért' $\rightarrow$ 'annak ellenére':

(16) ,elment azért e Fatens Aszon az rab személhez (noha ugyan haragossa volt néki) hogy eresszen megh a fiának" (Bosz. 2. 434. sz., 1751)

(17) ,,amint hogy az Utrumban feltött Kulcsarne oda ment az fatens Veinek hazahoz Nagy haragosa leven s kerte töle miert sütöd azt Matka meg eszitek vagy nem" (Bosz. 2. 26. sz., 1715)

Szintén okviszonyon alapul (1. 18) - és szintén az épp nem érvényes együttállásra utal -, amikor a tanúk arról számolnak be, hogy a boszorkánysággal vádolt személy közelében laktak, s mégsem tudnak beszámolni annak gyanús viselkedéséről:

(18) „Mint hogy e fatensel egy faluban lakván az kérdésbeli Rab aszon ahoz képest kicsinsigitül foghva jól ismeri $s$ ad 2dum mindetigh hallotta, hogy mind maga mind pedigh az elejis Boszorkányos Személleknek tartattak lennyi” (Bosz. 2. 426. sz., 1749)

(19) ,holott Korsósne még Leány korábanis az fatensnél lakván, s onnét mentis férhez, de semmi Boszorkányságát nem tapasztalta" (Bosz. 2. 348. sz., 1753)

Egyértelmü feltételességen alapuló megengedés ( $h a-i s)$ az anyagban nem mutatkozik igeneves szerkezettel, viszont van példa noha kötőszóval való megfelelésre, ráadásul kötőszós használatban sem választható el élesen, hogy az inkább ellentét, ráhagyás (jóllehet) vagy a feltétel és az időviszonyítás (noha, holott) kerül előtérbe az adott jelenet leírásakor (,jollehet hogj sok esztendőkig Seresnének szomszidságában lakot” vs. „noha gyermeksegetül fogvast mindenkor esmeri Szekelly Evátt Petranet"; ez a szabad váltakozás az ómagyarban is megfigyelhetó, RÁCZ 1995: 716-717).

5. Változási tendenciák. A sajátos jelentéstartalmú alárendelő mellékmondatok két fő változási iránya (az önálló, mellérendelő értékủvé válás és a mondatrésszé alakulás; HAADER 2008a: 84-85, 2017: 213-215) összevethető a tagmondat-kapcsolódást befolyásoló erőkre vonatkozó, elsősorban tipológiai megállapítással (LEHMANN 1988). A két ellentétes tendencia egyike az elemző (kidolgozó, elaboráló) szerkesztés, ilyenkor egy helyzet, szituáció (state of affairs) két önálló egységből áll, a viszonyukat pedig explicit kapcsolóelem jelzi. Az összekapcsoló (tömörítö) tendencia hatására viszont két helyzet egy összetett szituációként kialakított értelmezése valósul meg, általában teljes mondatból redu- 
kálódik, a fö állítmánnyal viszonyba kerül (beágyazódva a főmondatba, tipikusan névszói vagy határozói szerkezetként; LEHMANN 1988: 216-219). Diakrón öszszefüggésben ezeket a paramétereket az önállóságtól a beágyazottság iránya felé szokás értelmezni (a grammatikalizációval összefüggésben is, vö. GUGÁN 2006: 63). Ennek alapján látszólag könnyű felvázolni a két ellentétes változási irányt: a jóllehet, noha, bár bátor, akár stb. kötőszós szerkezetek képviselik az önállóságot - az ellentétes kötőszók halmozásával a mellérendelés felé mozdulva -, míg az implicit (és jelentéssűrítő) igeneves szerkezetek mondatrészértéküvé válnak:

(20) „Csudálva látták az Társaiis hogy olly eöregh ember leven annyit gyalogolhat" (Bosz. 2. 258. sz., 1686)

(21) és kináljátok meg az pinzzel Remete Mezőert, hogy vér lévén, meg nem kínált, s úgy adta el” (Kár. 85. sz., 1706)

Ezekben az esetekben a tagmondatok alanya azonos, nincs kapcsolóelem, nincs bővítményi koreferencia - a jelentéstartalom is többértelmü. Az itt vizsgált adatoknak csak kis százalékában jelenik meg ez a mondatrészértékü használat. Ahogy az ómagyar kapcsán megfogalmazódott: „,[a]z egyszerü mondatrész [...] alig képes ennek a bonyolult jelentés-sürítménynek a kifejezésére" (RÁCZ 1995: 711).

A magánéleti regiszterben vizsgálódva inkább az látszik, hogy számos esetben a kidolgozást eredményező tendencia kerül előtérbe. A magyar határozói igeneves szerkezet a tipológiai paraméterek szerint (LEHMANN 1988; GIVÓN 1990; KÖNIG - VAN DER AUWERA 1990) több igei kategóriával is bír: tagadható, független aspektusa van, saját alanya is lehet. További szempont, hogy a korszakban kötőszóval kapcsolódhat további tagmondatokhoz, ráadásul a fömondat és az igeneves tagmondat bővítményei között koreferencia lehet, ami növeli az önállóságát (vö. GUGÁN 2006: 69-72). Az egyes diskurzusfunkciók ugyanakkor különbségeket mutathatnak abban a tekintetben, hogy ezek közül mely kritériumok teljesülnek. Az igeneves szerkezet implicit vagy explicit saját alanya, valamint a két tagmondat egyes bővítményeinek koreferenciája általános lehetőségnek bizonyul (ahogy arra láttunk példákat). Ha viszont például feltételes jelentéstartalmat fejez ki az igeneves szerkezet, az a jelentés csak a szövegösszefüggésből azonosítható, kapcsolóelem nem jelzi (VARGA 2017).

A megengedés esetében ugyanakkor gyakran kapcsolóelemek is jelölik a viszonyokat (így az igenévnek nincs fölérendelt tagja a mondatban), ezáltal egy önállóbb szerkezeti megoldást eredményezve. Ezek általában a már fentebb is látott ellentétes kötőszók (mégis, mégsem, de, l. még (2), (12), (13), (19) számú példák):

(22) „Szomoruvan értem, hogi elebbeni betegeskedéséből vekonion jobbulvan es fordulvan kegyelmed egesseghre, méghis beteges allapattal vagion" (LobkP. 54. sz., 1638)

(23) „a Pápai Uramot emlegeti hogy ő kglme gazdag lévén mégis három esztendeig élt a beneficiummal" (Peregr. 62. sz., 1716)

A megengedés alapját adó igeneves tagmondatban is szerepelhet kötőszó, így a jelentéstartalom különlegesen könnyen azonosítható a szövegkörnyezetböl: 
(24) „Jóllehet egyik kezekbe esvén, nem bántották” (Bark. 50. sz., 1705)

(25) ,igen ritkán ha elmentis Esztendő álatt egyszer vagy kétszer noha Papista levén" (Bosz. 2. 433. sz., 1750)

(26) ,ujóbban megh nimula, harmad napigh, migh bizonyos Szentséget nyakára nem kötöttek, noha elméén lévén nem szolhatott” (Bosz. 2. 268. sz., 1731)

Az igei fóvariánshoz hasonlóan tehát a megengedő jelentésủ igeneves tagmondatok is a szerkezeti önállóság, kidolgozás tendenciáját mutatják. Ez illeszkedik a korszak igeneves használatába (legalábbis a magánéleti regiszter alapján), másrészt a jelentéstartalom összetettsége miatt is indokolt lehet a viszony nyomatékosítása. A tendenciák összjátékának időbeli tényezői egyelőre nem állapíthatók meg; a mondattani változásoknak a választhatóság miatt is jellegzetessége, hogy egyszerre lehet jelen egy adott időszakban a kezdőpont és a végpont (HAADER 2008a: 87).

Érdemes ugyanakkor megemlíteni, hogy nemcsak az igeneves használatban van kevés nyoma a mondatrészértékü megengedő határozói megoldásoknak. A korpuszban a dacára nem fordul elö, a létére eddig egyetlen adattat szerepel: „miert hagyja kijend ugymond magát illyen nagy Ember létére” (Bosz. 1. 101. sz., 1756). A korszakban azonban ingadozik az okhatározói használattal (tallózó gyüjtésböl idézve:) „Ettül ily tudálékos létére az egész falubeliek féltek” (MBF. 4., 1759; későbbi ingadozásra 1. SEBESTYÉN 1965: 146-147; BERRÁR 1977: 180). Mind az igeneves szerkezet, mind a létére egyaránt lehet a korszakban megengedő és okhatározói funkciójú is (így az utóbbi „eredeti” jelentése egyelöre nem mutatható ki). További kutatást igényel tehát, hogy a 19-20. század során kimutatható-e valamiféle versengés az igeneves szerkezet és az azóta névutóvá vált létére között. Tallózó gyüjtés alapján annyi mindenesetre elmondható, hogy az igeneves - mégis kötőszóval kapcsolt - szerkezeti megoldások nem példátlanok a középmagyar korszak végén, sőt azután sem:

(27),„[...] holott énnekem sokkal több lévén ottan, mégsem hoz bé háromszáz forintokat” (Naláczi Borbála levele Csáky Katalinnak, 1773: CsákyKL. 100)

(28) „énnekem elég rosszul esett tavaly, hogy elég kenderem lévén mégis nem kértek" (Szentpéteri Katalin levele Kossuth Ferenc intézőnek, 1778: SzentpéteriKL. 316)

(29) „Sopronyig egy huzomban jövén, 's egy nap se pihenvén; még-is olly elevenek voltak a meg-érkezéskor a' Lovaik” (Molnár, Némely nevezetes emberekről: 113, 1801: MTSzt.)

(30) Ily rút lévén mégis sok szépet hódított (Vajda, Gonosz házasság 34, 1848: MTSzt.)

6.Összefoglalás. Amegengedőjelentéstartalom kifejezése a középmagyarban nemcsak a kötőszókészlet változatossága miatt volt megállapodatlan, hanem a határozói igeneves tagmondatokkal szerkezeti variáció is árnyalta a képet. Ez utóbbi változat ritkább volt ugyan a magánéleti regiszterben, mint a fö kötószós változatok (jóllehet, noha), mégis határozottan gyakoribb, mint a bár bátor, akár és a holott kötőszós kapcsolódás, különös tekintettel a boszorkányperekre. A változási tendenciákat tekintve a tagmondatérték, az önállóság felé mozduló szerkesztés 
volt mindkét változatban a jellemző még a 18. század során is (a megengedő határozók lényegesen ritkábbak voltak igeneves használatban is). A jelentéstartalmat kötőszós és igeneves szerkezetekben egyaránt nyomatékosították szembeállító és megszorító ellentétes kapcsolóelemek is. Ez a közlésbeli igény valószínúleg a komplex jelentésnek is köszönhető, ugyanakkor nagyobb a kategóriák (ellentét és megengedés) közötti átjárás. A variáció esetleges társadalmi beágyazottságának és visszaszorulásának feltárása (amennyire az anyag lehetővé teszi, kvantitatív eszközök alkalmazásával) további kutatásokat igényel.

Kulcsszók: megengedő jelentéstartalom, mondattani variáció, pragmatikai variáció, középmagyar korszak, magánéleti regiszter.

\section{Források és hivatkozott irodalom}

BÁNRÉTI ZOLTÁN 1983. A megengedö kötőszók szintaxisáról és szemantikájáról. Nyelvtudományi Értekezések 117. Akadémiai Kiadó, Budapest.

Bark. = Barkóczy Krisztina levelei férjéhez, Károlyi Sándorhoz. Elsö kötet 1698-1711. Szerk. FogARASSY ZOLTÁN - KOVÁCS ÁGNES. Debreceni Egyetem Történeti Intézete, Debrecen, 2011.

BARTH, DAGMAR 2000. „That's true, although not really, but still: Expressing concession in spoken English. In: COUPER-KUHLEN, ELIZABETH - KorTMANN, BERND eds., Cause, condition, concession, contrast. Cognitive and discourse perspectives. Mouton de Gruyter, Berlin - New York. 411-432. https://doi.org/10.1515/9783110219043

BERRÁR JOLÁN 1956. A magyar megengedő mondatok kialakulásáról. Magyar Nyelv 52: $26-35$.

BERRÁR JOLÁN 1957. Magyar történeti mondattan. Tankönyvkiadó, Budapest.

BERRÁR JOLÁN 1977. Megjegyzések a sajátos jelentéstartalmú mellékmondatok kérdésköréhez. In: RÁCZ ENDRE - SZATHMÁRI ISTVÁN szerk., Tanulmányok a mai magyar nyelv mondattana köréböl. Tankönyvkiadó, Budapest. 171-187.

Bosz. 1-2. = Magyarországi boszorkányperek 1529-1768. Közreadja: SCHRAM FERENC. Akadémiai Kiadó, Budapest, 1970/1983.

Crevels, Mily 2000. Concession. A typological study. Amsterdam, University of Amsterdam. https://pure.uva.nl/ws/files/3091856/11689_Thesis.pdf (2017. 01. 15.)

CsákyKL. = „Minden örömöm elegyes volt bánattal”. Csáky Kata levelezése. Közreadja PAPP KLÁRA. Erdély-történeti Alapítvány, Debrecen, 2006.

DÖMÖTÖR ADRIENNE 2003. Szinonim mondatszerkezetek és formai változatok. Vonatkozó mellékmondatos alárendelések és párhuzamaik hat korai bibliafordítás tükrében. Magyar Nyelv 99: 448-466.

DuBOIS, SYLVIE - SANKOFF, DAVID 2001. The Variationist Approach toward Discourse Stuctural Effects and Socio-interactional Dynamics. In: SchIFFRIN, DEBORAH et al. eds., The Handbook of Discourse Analysis. Blackwell Ltd., Malden-Oxford. 282-303. https://doi.org/10.1002/9780470753460.ch16

Givón, TAlmy 1990. Syntax. A functional-typological introduction 2. John Benjamins Publishing Company, Amsterdam-Philadelphia.

Grote, BRIGITTE - LENKE, NiLS - Stede, MANFRED 1997. Ma(r)king concessions in English and German. Discourse Processes 24/1: 87-117. http://dx.doi.org/10.1080/[-] 01638539709545008 
GugÁn Katalin 2002. Syntactic Synonymy: A case study. Acta Linguistica Hungarica 49: 23-49. https://doi.org/10.1556/ALing.49.2002.1.4

GuGÁN KATALIN 2006. A szintaktikai változások feltételezett egyirányúságáról. Nyelvtudományi Közlemények 103: 61-74.

GUGÁN KATALIN 2015. Hol volt? Hol nem volt? A tagmondattörlő grammatikalizációs folyamatokról a lévén és a lehet grammatikalizációja kapcsán. Magyar Nyelv 111: 38-53. https://doi.org/10.18349/magyarnyelv.2015.1.38

HAADER LEA 1992. Az okhatározói mondat problematikája az ómagyar korban. In: KoZOCSA SÁNDOR GÉZA - LACZKÓ KRISZTINA szerk., Emlékkönyv Rácz Endre hetvenedik születésnapjára. ELTE BTK Mai Magyar Nyelvi Tanszék, Budapest. 97-104.

HAADER LEA 1995. Az alárendelő mondatok. Az alanyi, állítmányi, határozói mellékmondatok. In: TNyt. II/2: 506-665.

HAADER LEA 2000. Szemantikai többlettartalmat hordozó mellékmondatok: a sajátos jelentéstartalmú mellékmondatok. In: KESZLER BORBÁLA szerk., Magyar grammatika. Nemzeti Tankönyvkiadó, Budapest. 518-534.

HAADER LeA 2003. Az összetett mondat. Mondattan. In. KISS JenÖ - PuszTAI FerenC szerk., Magyar nyelvtörténet. Akadémiai Kiadó, Budapest. 677-690.

HAADER LEA 2004. Változások a történeti szintaxisban - pragmatikai háttérrel. Magyar Nyelvör 128: 464-469.

HAADER LEA 2008a. Az alárendelő mondatok változási irányáról. In: HAADER LEA HORVÁTH LÁSZLÓ szerk., Tanulmányok a középmagyar kor mondattana köréböl. Tinta Könyvkiadó, Budapest. 77-87.

HAADER LEA 2008b. A mellékmondatfajták és a szövegtípusok viszonyáról. In: ToLCSVAI NAGY GÁBOR - TÁTRAI SzILÁRD szerk., Szöveg, szövegtípus, nyelvtan. Tinta Könyvkiadó, Budapest. 251-259.

HAADER LEA 2017. Az összetett mondatok. In: KISS JENŐ - PUSZTAI FERENC szerk., $A$ magyar nyelvtörténet kézikönyve. Tinta Könyvkiadó, Budapest. 209-225. (Megjelenés alatt.)

HeInE, BERND - KUTEVA, TANIA 2002. World Lexicon of Grammaticalization. Cambridge University Press, Cambridge. https://doi.org/10.1017/cbo9780511613463

HORVÁTH LÁSZLÓ 1991. Három vázlatos szinkrón metszet határozói igeneveink történetéből. Nyelvtudományi Értekezések 133. Akadémiai Kiadó, Budapest.

KÁROLY SÁNDOR 1980. Hozzászólás a „Történeti nyelvtanírásunk helyzete és feladatai” c. előadáshoz. In: IMRE SAMU - SZATHMÁRI ISTVÁN - SzÜCS LÁSZLÓ szerk., A magyar nyelv grammatikája. Nyelvtudományi Értekezések 104. Akadémiai Kiadó, Budapest. 41-53.

JordK. = Jordánszky-kódex. 1516-1519. A szöveget gondozta SzÁNTÓ TIBOR. Helikon, Budapest, 1984. Régi Magyar Nyelvemlékek 5.

Kár. = Károlyi Sándor levelei feleségéhez, 1704-1724. Szerk., jegyzetekkel és mellékletekkel ellátta KovÁcs ÁGNES. Közread. CsOBÓ PÉTER et al. Kossuth Lajos Tudományegyetem, Debrecen, 1994.

KENESEI ISTVÁN 1992. A független és a kategoriális alárendelés. Az alárendelt mondatok szerkezete. In: KIEFER FERENC szerk., Sturkturális magyar nyelvtan 1. Mondattan. Akadémiai Kiadó, Budapest. 531-709.

É. KisS KATALIN 1998. A független alárendelés. Az alárendelő összetett mondat. In: É. KISS KATALIN - KIEFER FERENC - SIPTÁR PÉTER, Új magyar nyelvtan. Osiris Kiadó, Budapest. 127-155. 
KolozsBosz. = Kolozsvári boszorkányperek. 1564-1743. Szerk. PAKÓ LÁszLÓ - TÓTH G. PÉTER. Balassi Kiadó, Budapest, 2014.

KÖNIG, EKKEHARD 1985. On the history of concessive connectives in English. Diachronic and synchronic evidence. Lingua 66: 1-19. https://doi.org/10.1016/s0024-3841(85)[-] 90240-2

KÖNIG, EKKEHARD - VAN DER AUWERA, JOHAN 1990. Adverbial participles, gerunds and absolute constructions in the languages of Europe. In: BECHERT, JOHANNES - BERNINI, GIULIANO - BURIDANT, ClAUDE eds., Toward a Typology of European Languages. Mouton de Gruyter. Berlin - New York. 337-356. https://doi.org/10.1515/9783110863178

KÖNIG, EKKEHARD 2006. Concessive Clauses. In: KEITH BROWN ed., Encyclopaedia of Language and Linguistics. 2nd ed. Elsevier, Oxford. 820-824. https://doi.org/[-] 10.1016/b0-08-044854-2/00277-7

Könyvecse $=$ Könyvecse az szent apostoloknak méltóságokról. A nyelvemlék hasonmása és betühü átirata bevezetéssel és jegyzetekkel. A bevezetést és a jegyzeteket írta PUSZTAi ISTVÁN. Régi Magyar Kódexek 1. Magyar Nyelvtudományi Társaság, Budapest. 1985.

LeHMANN, Christian 1988. Towards a typology of clause linkage. In: Haiman, J. Thompson, S. A. eds., Clause Combining in Grammar and Discourse. John Benjamins Publishing Company, Amsterdam - Philadelphia. 181-225. https://doi.org/[-] 10.1075/tsl.18.09leh

LENGYEL KLÁRA 1989. Határozói igeneveink szófajváltásáról. In: RÁCZ ENDRE szerk., Fejezetek a magyar leíró nyelvtan köréböl. Tankönyvkiadó, Budapest. 181-217.

LobkP. = „Im küttem én orvosságot”: Lobkowitz Poppel Éva levelezése 1622-1640. Öszszegyüjtötte, sajtó alá rendezte, a kísérő tanulmányt írta KINCSES KATALIN. ELTE Koraújkori Történeti Tanszék - Koraújkori Társaság, Budapest, 1993.

Macaulay, Ronald 2002. Discourse Variation. In: Chambers, Jack K. - Trudgill, PETER - SCHILling-ESTES, NATALIE eds., The Handbook of Language Variation and Change. Blackwell Publishers Ltd., Malden-Oxford-Carlton. 283-305. https://doi.[-] org/10.1002/9780470756591.ch11

MBF. 4. = A magyarországi boszorkányság forrásai 4. Szerk. TÓTH G. PÉTER. Balassi Kiadó, Budapest, 2005.

MTSzt. = Magyar Történeti Szövegtár. http://www.nytud.hu/hhc

Nád. = Nádasdy Tamás nádor családi levelezése. Szerk. KÁROLYI ÁRPÁD - SZALAY JÓZSEF. Akadémiai Kiadó, Budapest, 1882.

NovÁK, ATtila - GugÁn, KATALIN - VARgA, MóniKA - DöMÖTÖR, AdRIENNE 2017. Creation of an annotated corpus of Old and Middle Hungarian court records and private correspondence. Language Resources and Evaluation. (Megjelenés alatt. L. még http://www.nytud.hu/oszt/nyelvtort/projektbemutato.pdf.)

Peregr. $=$ Peregrinuslevelek 1711-1750. Szerk. HofFMANN GIZELLA. JATE, Szeged, 1980. RÁCZ ENDRE 1991. Valvád, valvátok. In: HAJDÚ MIHÁLY - KISS JENŐ szerk., Emlékkönyv Benkö Loránd hetvenedik születésnapjára. ELTE, Budapest. 546-550.

RÁCZ ENDRE 1995. Nem mondatrészkifejtő sajátos jelentéstartalmú mellékmondatok. In: TNyt. II/2: 694-718.

SCHNEIDER, EdGAR W. 2002. Investigating Variation and Change in Written Documents. In: Chambers, JACK K. - Trudgill, Peter - Schilling-Estes, NATAliE eds., The Handbook of Language Variation and Change. Blackwell Publishers Ltd., MaldenOxford-Carlton. 67-96. https://doi.org/10.1002/9780470756591.ch3 
SEBESTyÉn ÁrpÁD 1965. A magyar nyelv névutórendszere. Akadémiai Kiadó, Budapest. SzentpéteriKL. = „Semmi újságot irni nem tudok”. Ráday Gedeonné Szentpéteri Katalin levelezése. Közreadja BERECz ÁGNES. Balassi Kiadó, Budapest, 2016.

Tagliamonte, SAly A. 2010. Linguistic Variable. In: Analysing Sociolinguistic Variation. Cambridge University Press, Cambridge. 70-98. https://doi.org/10.1017/CBO9[-] 780511801624

Tagliamonte, Saly A. 2012. Variationist Sociolinguistics: Change, Observation, Interpretation. Wiley-Blackwell, Oxford.

Tel. = Két vitéz nemes úr. Telegdy Pál és János levelezése a XVI. század végéröl. Közreadja ECKHARDT SÁNDOR. Királyi Magyar Pázmány Péter Tudományegyetem, Budapest, 1944.

TMK. $=$ Történeti magánéleti korpusz. http://tmk.nytud.hu

TNyt. II/2. = A magyar nyelv történeti nyelvtana II/2. A kései ómagyar kor. Mondattan. Szöveggrammatika. Főszerk. BENKÖ LORÁND. Akadémiai Kiadó, Budapest, 1995.

VARGA MÓNIKA 2015. A határozói igenév és az igei állítmány viszonyáról boszorkányperekben. Magyar Nyelv 111: 54-67. https://doi.org/10.18349/magyarnyelv.2015.1.54

VARGA MÓNIKA 2017. Feltételes jelentéstartalmú mondatszerkezetek alakulásáról középmagyar szövegekben. Kézirat.

WEINREICH, URIEL - LABOV, WILLIAM - HERZOG, MARVIN I. 1968. Empirical Foundations for a Theory of Language Change. In: LEHMANN, WinfRED P. - MALKIEL, YAKOV eds., Directions for Historical Linguistics. Austin, University of Texas Press. 95-195.

Zr. = A két Zrínyi Miklós körmendi levelei. Közreadja IVÁNYI BÉLA. Királyi Magyar Pázmány Péter Tudományegyetem, Budapest, 1943.

\section{On the marking of concession during the Middle Hungarian period}

The paper investigates variation in syntactic constructions expressing concession in 16-18thcentury Hungarian texts, using primarily the Historical Corpus of Private Texts. The expression of concession was rather variegated in Middle Hungarian, but not simply due to the multifariousness of the stock of conjunctions; the overall picture was also made more nuanced by structural and pragmatic variation involving participial clauses, little discussed in the literature so far. A structural shift towards independent, full-fledged clauses characterised both subtypes even as late as in the 18th century. Probably due to its complexity, concessive meaning was reinforced by linking elements expressing contrast or restriction both in the variants involving conjunctions and in the participial ones.

Keywords: concession, syntactic variation, pragmatic variation, Middle Hungarian period, informal language use.

VARGA MÓNIKA

Eötvös Loránd Tudományegyetem MTA Nyelvtudományi Intézet 